Indigenous Ethnicity and Entrepreneurial Success in Africa

Some Evidence from Ethiopia

Taye Mengistae
Manufacturing businesses

owned by an indigenous

ethnic group, the Gurage,

typically perform better than

those of members of any

other (major or minority)

groups in Ethiopia. Gurage-

owned businesses are

normally larger and grow

faster. Yet Gurage business

owners typically are less

educated than their

counterparts in other groups

and have less formal

vocational training

The World Bank

Development Research Group

Macroeconomics and Growth

January 2001 


\section{Summary findings}

Researchers have recently been asking why Asian and European minorities in Africa seem to be more successful in business than are people of indigenous ethnicity. Mengistae draws attention to the significant disparity in business ownership and performance that seems to exist among African ethnic groups as well.

After analyzing a random selection of small to medium-size manufacturers in Ethiopia, he finds that establishments owned by an indigenous minority ethnic group, the Gurage, typically perform better than those owned by other (major or minority) groups.

Other things being equal, Gurage-owned businesses are normally larger, partly because they are bigger as startups and partly because they grow faster. And yet Gurage business owners are the least educated ethnic group in the sample. Because the size and growth rate of a business also increases with the entrepreneur's education, the performance of other businesses would have been even worse if their owners hadn't been better educated than the Gurage. Indeed, dropping education variables from the size determination equation drastically reduces the estimated advantage of Gurage-run businesses.

This suggests that the observed effect of ethnicity could be indicative of intergroup differences in unmeasured ability. More important, it means that whether or not the effect will persist in the long run wili depend on the trend in interethnic differences in investment in education.

This paper-a product of Macroeconomics and Growth, Development Research Group-is part of a larger effort in the group to investigate the microeconomic foundation of the association between ethnic diversity and the poor growth performance that seems to characterize Sub-Saharan Africa. The study was funded by the Bank's Research Support Budget under the research project "The Economics of Ethnicity and Entrepreneurship in Africa." Copies of this paper are available free from the World Bank, $1818 \mathrm{H}$ Street NW, Washington, DC 20433. Please contact Rina Bonfield, room MC3-354, telephone 202-473-1248, fax 202-522-3518, email address abonfield@worldbank.org. Policy Research Working Papers are also posted on the Web at http://econ.worldbank.org/. The author may be contacted at tmengistae@worldbank.org. January 2001. (26 pages)

The Policy Research Working Paper Series disseminates the findings of work in progress to encourage the exchange of ideas about development issues. An objective of the series is to get the findings out quickly, even if the presentations are less than fully polished. The papers carry the names of the authors and should be cited accordingly. The findings, interpretations, and conclusions expressed in this paper are entirely those of the authors. They do not necessarily represent the view of the World Bank, its Executive Directors, or the countries they represent. 


\title{
Indigenous Ethnicity and Entrepreneurial Success in Africa: Some Evidence from Ethiopia
}

\author{
Taye Mengistae ${ }^{*}$
}

* The World Bank, 1818 H Street N.W., Washington, DC 20433, U. S.A. Internet: tmengistae@worldbank.org 



\section{Introduction}

In many countries in Sub-Saharan Africa, the ownership of medium and large- scale businesses is concentrated in the hands of members of foreign minority ethnic groups: for example, Indians in Kenya, Europeans in Zimbabwe, and Europeans and Arabs in Cote d'Ivoire. 'Based on an analysis of cross-country enterprise survey data, Ramchandran and Shah (1999) suggest that this is in part because businesses owned by members of these groups perform better than those run by indigenous entrepreneurs. Controlling for initial size, age, and industry, Asian or European- owned businesses grow faster than those run by blacks. In the case of Zimbabwe, Raturi and Swamy (1999) show that it is unlikely that this is because formal credit institutions discriminate against businesses owned by blacks, for which they found no evidence. Using data from Kenya and Zimbabwe, Fafchamps (2000) confirms this result, but also shows that Asian or European businesses have better access to trade credit. He interprets this as evidence that ethnic networking in contract enforcement may be the reason why the Asians and the Europeans are doing better. $^{2}$

In this paper I pursue the same theme of ethnicity effects in entrepreneurial success in Africa, but with a shift in focus to differences between indigenous ethnic groups, and the role that the distribution of skills or ability might play in generating the effects. Even in countries where immigrant ethnic groups have high profiles in business ownership, indigenous entrepreneurs own most small businesses and a significant share of medium sized establishments. More importantly, local entrepreneurs themselves are not a homogenous ethnic group. And, as seems to be the case in many other multi-ethnic societies, some groups are popularly perceived to do better in business than others. Should the perception be correct, then disparity in business ownership and performance among indigenous ethnic groups deserves explanation no less than does the relative

\footnotetext{
'A number of studies provide evidence for similar disparity among ethnic groups in the United States, historically as well as among contemporary immigrants. See, for example, Aldrich and Waldinger (1990) and Fairelie and Meyer (1996).

${ }^{2}$ See also Fisman (2000) for similar results on a larger data set that includes observations from Tanzania and Zambia as well.
} 
entrepreneurial success of foreign ethnic groups. Part of this explanation could be unequal distribution of business skills or ability across ethnic groups that may be transient or more or less permanent.

The paper is based on an analysis of data from a business survey in Ethiopia that is very similar to surveys on which the studies just cited drew. Ethiopia is a country of extreme ethnic diversity and, unlike most of the countries covered by the other surveys, does not have a substantial business community of foreign ethnicity. ${ }^{3}$ The question I pose is whether or not businesses owned by members of some indigenous ethnic groups normally perform better than those of others. If they do, how far can we explain the performance differential by inter-ethnic differences in skills or ability?

The meaning of 'ethnicity' seems to vary considerably within and across disciplines, as does that of 'entrepreneurship'. In this paper I follow Knight's definition of the entrepreneur as an owner operator of a business enterprise, combining the functions of management and risk taking (Knight, 1921). The analysis is therefore confined to ownermanaged establishments. I also adopt Yinger's definition of an ethnic group as a 'segment of a larger society whose members are distinguished from others by some mixture of language, religion, race and ancestral homeland'. There are scores of groups in Ethiopia that satisfy this definition. Of these the Amhara, the Gurage, the Oromo and the Tigrawai are the largest, and have a combined share of more than 75 percent of the current total population of some 60 million. ${ }^{4}$

A look at the distribution of my sample of businesses suggests that there are large disparities in business ownership between ethnic groups. The rate of business ownership is far higher for the Gurage than for any other group. The Gurage constitute less than 5 percent of the labor force of the region from which the data were collected, and yet nearly a third of the businesses in the sample are Gurage- owned. With a share of 40 percent of establishments, the Amhara, rather than the Gurage, constitute the largest ethnic group of

${ }^{3}$ Ethiopia did have a sizeable business community of European extraction prior to the military takeover of 1974. 
business owners in the sample. However, the share of the Amhara in the regional workforce is of the same order of magnitude. Consequently, the rate of business ownership of the Amhara is far smaller than that of the Gurage as is that of other ethnic groups.

Do Gurage-run enterprises also perform better than businesses run by members of other indigenous ethnic groups? The answer is yes. Controlling for the date of start-up, the industry of operation, the time of observation, the education and prior industry experience of the owner and unobserved establishment effects, a Gurage-run business is, on the average, 26 percent larger than an Amharic-run business. It is also 39 percent larger than a business run by a member of any other ethnic group. Part of this size advantage of Gurge-owned businesses is due to their starting up bigger. Part is because they subsequently grow faster. The start-up size of the average Gurage-run business is 25 percent larger than the start-up size of the average business run by a member of any other ethnic group. When we control for start-up size, the average Gurage-run business has an annual growth rate advantage of 5.2 percent over the average Amharic- run business. It also has a growth rate advantage of 10.1 per cent per annum over the average business run by a member of other non-Amharic ethnic groups.

These results are all the more interesting because Gurage business owners are also the least educated ethnic group in the sample. Not only do they have the lowest average number of years of schooling, but a Gurage business owners is also less likely to have had formal vocational training than an entrepreneur of any other ethnic identitiy. At first sight this would seem to suggest that education is not a factor in entrepreneurial success. However, the evidence is to the contrary: other things being equal, entrepreneurs with more years of schooling or some formal vocational training run larger businesses, again partly because they start out bigger, and partly because their businesses grow significantly faster ${ }^{5}$. Indeed, dropping education variables from the list of controls sharply reduces the size advantage of Gurage-run businesses. It also significantly lowers

\footnotetext{
${ }^{4}$ Each of the four groups listed has a distinctive native language.
} 
their advantage in terms of rate of growth. I interpret this to mean that non-Gurage businesses would have been even less successful than Gurage-run businesses were their owners less educated than they actually are.

This in turn suggests that part of the secret of the relative success of Gurage-run businesses could be the superiority of Gurage entrepreneurs as a group in terms of some unmeasured ability: greater drive or energy, for example. More importantly, it also implies that the observed ethnicity effect in entrepreneurial success need not be permanent. If the effect of education on business size or growth is monotonic over a reasonably wide range, then, in the long run, the advantage of Gurage-run businesses can be eroded completely if the rate of investment in education by other ethnic groups sufficiently exceeds that of the Gurage.

The rest of the paper is organized as follows. Section 2 justifies the use of establishment size and growth as measures of entrepreneurial performance and sets out the econometric framework of the paper. Section 3 discusses data and variables. Details of findings are reported in Section 4 . I conclude in section 5.

\section{The Determination of Business Size}

A conceptual framework that seems to be well suited for the analysis of the role of ethnicity in entrepreneurial success is the hypothesis of competitive selection in the dynamics of firms. This is the idea that the evolution of a competitive industry is driven by a process of selection arising from the heterogeneity of producers, that is, from the fact that no two producers can have the same level of output from a given mix of traded factor inputs. Even under pure competition, some firms will normally be more productive than others, either because they are always better managed, or because they are better endowed with some other source of quasi-rent such as advantageous location or exclusive knowledge of pieces of technical information. The resulting inter-firm differences in unit costs prompt a process of selection whereby only producers for which the productivity of traded factor inputs exceeds a critical threshold enter an industry (Lucas, 1978; Lippman

\footnotetext{
${ }^{5}$ Ramchandran and Shah (1999) find the same result for a sample of businesses pooled from manufacturing business surveys for Kenya, Zambia, Zimbabwe and Tanzania.
} 
and Rumelt, 1982) or survive and grow in it (Jovanovic, 1982; Hopenhayn, 1992).

Selection also means dispersion in the size of survivors observed at any fixed point in time, whereby the more productive businesses are also bigger either because they started out bigger or because they have grown faster.

The hypothesis suggests a number of alternative indicators of the success of a business firm, namely, productivity, current size and longevity. Because of lack of data on a control group of non-survivors, the last of these cannot be used in the present analysis. ${ }^{6}$ And the measurement of productivity with the kind of data analyzed here requires the imposition of rather restrictive assumptions about the technology of production. ${ }^{7}$ More importantly, the use of productivity as a measure of entrepreneurial performance requires a longer time series of observations than I actually have. ${ }^{8}$ The indicator of performance that I use in the paper is therefore current size, which must be a sufficient statistic for past realizations of productivity if the hypothesis does indeed hold.

The question of interest is then whether or not the size of an entrepreneurial business depends on the ethnicity of its owner and, assuming it does, the extent to which this is because of inter-ethnic differences in business skills or ability. Let $S_{i t}$ be the current size of business $i$ in terms of employment, assets or turnover, and $S_{i 0}$ the size of the same business at its start-up. The simplest specification of the determination of $S_{i r}$ is one in which businesses that are identical except for differences in $S_{i 0}$ would grow subject Gibrat's Law, that is, at the same mean rate $\alpha$ regardless of scale at start-up. In this case we have $S_{i t}=e^{\alpha} S_{0 i} U_{i t}$, where $U_{i t}$ is a random error term the log of which has zero mean. However, recent empirical studies do not seem to support this pattern, the most common finding being that smaller firms grow faster. Among possible explanations for this are dynamic economies of scale and the gradual diffusion of new techniques of production

\footnotetext{
${ }^{6}$ This means that inter-ethnic differences in business performance as reported later strictly apply to the more successful segment of entrepreneurs within each group.

${ }^{7}$ In particular it requires the assumption of a constant- returns- to scale production function because of the difficulty of observing capital inputs.

${ }^{8}$ What we need in this case is observation of the time path of productivity from start-up to the present, rather than data points of the immediate past.
} 
(Jovanovic and Macdonald, 1994). In the context of existing selection models the phenomenon arises from inter-firm productivity differentials that are permanent but are learnt about only through experience (Jovanovic, 1982), or, are known and transient but are competed away only gradually (Hopenhayn, 1992). Yet another model implies that smaller firms would grow slower as a result of differential rates of investment in R\&D under monopolistic competition (Nelson and Winter, 1982). Once initial size is controlled for the influence of age on growth is ambiguous in all of these models. However, another common finding of most empirical studies is that the age of a firm is a major influence on its growth performance. A more general specification of the size determination equation is therefore $S_{i t}=e^{\alpha+f\left(A_{i l}\right)} S_{i 0}^{\gamma} U_{i t}$, where $A_{i t}$ is the current age of $i$, $\gamma$ is a constants which is unity under Gibrat's Law, less than unity if smaller firms grow faster and greater than unity if smaller firms grow slower. Since it is possible that the very differences in productivity that lead to a size effect in growth also lead to differences in the expected growth rate of firms of the same age and the same initial size, an even more general specification is

$$
\ln S_{i t}=\alpha_{i t}+f\left(A_{i t}\right)+\gamma \ln S_{i 0}+u_{i t}
$$

where $u_{i t}=\ln U_{i t}$ and the firm and time specific term $\alpha_{i t}$ now replaces $\alpha$.

Assume further that $\alpha_{i t}$ is a linear combination of a common element $\alpha_{0}$, a time or business cycle effect $\alpha_{t}$, an unobservable and time-invariant establishment-specific element $\alpha_{i}$, and observable entrepreneurial characteristics $Z_{j i}, j=1, . ., k$. A more informative version of equation (1) would then be

$$
\ln S_{i t}=a_{0}+\alpha_{t}+\alpha_{i}+\sum_{j=1}^{k} \alpha_{j} Z_{j i}+f\left(A_{i t}\right)+\gamma \ln S_{i 0}+u_{i t}
$$


Assume finally that start-up size, $S_{i 0}$, itself is partly determined by the very sources of productivity that determine growth and is also log-linear in those sources so that

$\ln S_{i 0}=\lambda_{0}+\lambda_{i}+\sum \lambda_{j} Z_{j i}$. We then have

$$
\ln S_{i t}=a_{0}^{\prime}+\alpha_{i}+\alpha_{i}^{\prime}+\sum_{j=1}^{k} \alpha_{j}^{\prime} Z_{j i}+f\left(A_{i T}\right)+u_{i T}
$$

where $\alpha_{0}^{\prime}=\alpha_{0}+\lambda_{0} \gamma, \alpha_{i}^{\prime}=\alpha_{i}+\lambda_{i} \gamma$, and $\alpha_{j}^{\prime}=\alpha_{j}+\gamma \lambda_{j}$

My strategy for testing for ethnicity effects in entrepreneurial performance consists in the inclusion of the ethnicity of business owners among the $Z_{j}$ 's. The estimation of equation (3) yields an estimate of the overall (marginal) effect $\alpha_{j}^{\prime}=\alpha_{j}+\gamma \lambda_{j}$ of $Z_{j}$ on current business size. We can then estimate equation (2) to see how this overall effect divides into its two components, namely, $\gamma \lambda_{j}$, which is transmitted through start-up size, and $\alpha_{j}$, which is the effect on growth of the business since start-up. Dividing $\alpha_{j}$ by the age of the business, $A_{i l}$, gives us the effect of $Z_{j}$ on the annual average growth rate of business $i$ since start-up. This is of course a random variable. However, we can obtain an estimate of its mean by estimating equation (2) with the average annual rate of growth of the business as the left-hand side variable. Subtracting the log of start-up size from (2) and dividing by the age of the business gives

$g_{i t}=\left(\alpha_{0}+\alpha_{t}+\alpha_{i}\right) / A_{i t}+\sum_{j=1}^{k} \alpha_{j}\left(Z_{j i} / A_{i t}\right)+h\left(A_{i t}\right)+(\gamma-1)\left(\ln S_{i 0} / A_{i t}\right)+u_{i t}^{*}$

where, $g_{i t}=\left(\ln S_{i t}-\ln S_{i 0}\right) / A_{i t}, h\left(A_{i t}\right)=f\left(A_{i t}\right) / A_{i t}$ and $u_{i t}^{*}=u_{i t} / A_{i t}$. Let $E\left(\alpha_{j} / A_{i t}\right)=\alpha_{A j}$, $E\left(\alpha_{k} / A_{i l}\right)=\alpha_{A k} k=0, t, i$, and $E\left[(\gamma-1) / A_{i t}\right]=c_{A}$. An estimate of the expected effect, $\alpha_{A j}$, of $Z_{j}$ on the average annual growth rate since start up can then be obtained by estimating $g_{i t}=\alpha_{A 0}+\alpha_{A t}+\alpha_{A i}+\sum_{j=1}^{k} \alpha_{A j} Z_{j i}+E\left[h\left(A_{i t}\right)\right]+c_{A} \ln S_{i 0}+u_{i t}^{*}$ 
Note that the parameter $\alpha_{A j}$ captures only the direct effect of $Z_{j}$ on the annual average growth rate since start-up. To obtain an estimate of the mean of the overall effect of $Z_{j}$ on the average annual growth rate we need to estimate

$g_{i t}=\alpha_{A 0}^{\prime}+\alpha_{A t}^{\prime}+\alpha_{A i}^{\prime}+\sum_{j=1}^{k} \alpha_{A j}^{\prime} Z_{j i}+E\left[h\left(A_{i t}\right)\right]+u_{i t}^{*}$

where, again on the assumption $\ln S_{i 0}=\lambda_{0}+\lambda_{i}+\sum \lambda_{j} Z_{j i}$, we have $\alpha_{A 0}^{\prime}=\alpha_{A 0}+c_{A} \lambda_{0}=$, $\alpha_{A i}^{\prime}=\alpha_{A i}+c_{A} \lambda_{i}$ and $\alpha_{A j}^{\prime}=\alpha_{A j}+c_{A} \lambda_{j}$. Subtracting the estimate $\alpha_{A j}$ that we obtain based on (4) from the estimate of $\alpha_{A j}^{\prime}$ obtained based on (5) gives us an estimate of the effect, $c_{A} \lambda_{j}$, that $Z_{j}$ has on $g_{i t}$ through its influence on start-up size only. This in turn has two components: the effect, $\lambda_{j}$, of $Z_{j}$ on start-up size, and the effect, $c_{A j}$, of start-up size on $g_{i l}$.

The analysis of data reported in Section 4 of the paper is based on the estimation of equations (2) to (5) by GLS on the following assumptions: (a) the establishment effects, $\alpha_{i}, \alpha_{i}^{\prime}, \alpha_{A i}$, and $\alpha_{A i}^{\prime}$ are all random variables; (b) the error terms, $u_{i i}$ and $u_{i t}^{\prime}$ are each distributed iid with zero mean and independently of the establishment effects, the $Z_{j}$ 's and $f\left(A_{i t}\right)$; and (c) $f\left(A_{i t}\right)$ is linear in the log of $A_{i t}$. I should perhaps warn at this point against possible confusion of the two equations with standard business growth equations estimated in, for example, Evans (1987), Hall (1987) and Dunne and Hughes (1994). In the estimation of standard establishment growth equations growth is observed over the same time interval. This clearly is not the case here since the initial point in time is the date of start-up, which normally differs from establishment to establishment. While this would not affect the interpretation of the coefficients of initial size or of entrepreneurial characteristics in an estimated growth equation, it changes radically the meaning of the coefficients of the age variable in the same equation. In standard growth equations this coefficient would rightly be assumed to measure some kind of life cycle effect. In 
contrast, the coefficient of the age variable in equation (4) or equation (5) above mixes up the same effect with start-up time effects and is, in this sense, difficult to interpret.

\section{Data and Variables}

My data sources are the 1993 and 1995 waves of the Addis Ababa Industrial Enterprises Survey (AAIES), which covered a random selection of manufacturing establishments in the Addis Ababa region. With an estimated population of around 3.5 million, the region is Ethiopia's commercial and political center and has significant presence of almost all ethnic groups of the country. It accounts for some 80 percent of the country's industrial output and is regarded as something of a melting pot in which inter-ethnic differences appear to have diminished in many respects over the last century. The 1993 wave of the AAIES covered 220 manufacturing establishments of which 190 were private sector establishments. The sample frame the survey was the 1993 edition of the official register of manufacturing establishments of the then Ministry of Industry. Although the sample happens to be concentrated in half a dozen industries, there was no restriction on sectors of industry in its selection. However, the probability of selection assigned to each establishment on the register was proportional to the establishment's share in the total employment of all establishments on the register. Of the 190 private sector establishments 152 were revisited by the 1995 wave which also collected data for the 1994 fiscal year. The data that are actually analyzed here relate to 292 observations on 114 of the owner- manage establishments covered by the revisit. The other 38 establishments were excluded either because they were not owner-managed or because they did not supply information on an essential variable. Descriptive statistics of the variables of interest for this sub-group of establishments are given in Table 1.

Although information is available on the sales and assets of all the 114 establishments, I measure current size only by the number of full-time observations at the end of a fiscal year. This is partly because appropriate deflators for star-up sizes in terms of sales or assets are not available. Start-up size is defined as the number of full-time employees at the time of the start of operations. The age of the establishment is defined as the number 
of years since its founding. Almost all of the establishments fall in the small to medium scale category with a mean employment size of 16 and a standard deviation of 21 . The mean age of a business is 14 years with a standard deviation of 11 years.

Just under a third of owners in the sample had at least one other business in some other line of activity, mainly in trade. Strictly speaking the measure of business size that matters from the point of view of measuring entrepreneurial success is the size of all owned businesses. Unfortunately, I cannot use this measure for lack of data on the employment size of other businesses. I am therefore including a dummy variable on the ownership of other businesses among $Z_{j}$ 's as a second best alternative. Industry dummies constitute a second set of controls among the $Z_{j}$ 's. The coefficients of these are intended to capture inter-industry differences in capital intensity in the size equations and industry effects in the growth equations. These are complemented by one dummy variable each for the years 1994 and 1995. About one-third of businesses in the sample are in garments and leather goods production against one-fifth in textiles, about a quarter in woodwork or metalwork, and another quarter in what I have grouped as "other industries".

Also included in the $Z_{j}$ 's are variables relating to three entrepreneurial characteristics, of which one is the ethnicity of the owner. Although there are half a dozen ethnic groups of business owners in the sample, just under three quarters of the businesses are owned by two groups, namely, the Amhara and the Gurage. I have included a dummy for each of these two groups among the $Z_{j}$ 's. The other two entrepreneurial characteristics included are the education of the owner and his or her prior work experience in the current industry. I measure educational attainment of a business owner in terms of two variables, namely, the number of years of schooling and a dummy variable for having had formal vocational training. The motivation for the inclusion of these variables among potential determinants of business size or growth is the hypothesis that schooling or vocational training adds to the business skills of an entrepreneur. In existing models of competitive selection skill differences among business owners are assumed to be unobservable. If 
such differences do indeed account for any part of observed differentials in business performance, one would expect differences in observable sources of skill to matter as well. On the other hand we should be wary of attributing performance differentials to differences in unmeasured entrepreneurial ability in a setting where the performance of a business clearly does not depend on the training or the experience of its manager. Among existing studies, Bates (1990) finds that the probability of survival of a small business in the United States increases with the level of education of the business owner while Ramachandran and Shah (1999) find business growth to increase with entrepreneurial schooling in four African countries.

It is likely that some of the entrepreneurial skills that determine the performance of an establishment are industry specific. I assume that, given the age of the establishment, the accumulation of such skills by the owner depends on the length of work experience he or she had in the industry prior to setting up or acquiring the establishment. It is also possible that the specific form of this experience matters. Although I do not have data on the duration of individual forms of prior industry experience, information is available as to which of the following forms applied to a business owner: engagement as a family worker, working as a regular employee, and being self-employed. A dummy variable indicating each of these forms is include among the $Z_{j}$ 's. In an analysis of a sample of Ghanaian logging businesses, Martin and Page (1983) find the length of prior industry experience of owners to be a significant influence on productivity. I am not aware of studies in which the effect of particular forms of the same experience is assessed. However, Lenz and Laband (1990) and Bates (1990) provide indirect evidence on the role of prior industry experience as a family worker. The former found that small businesses that were inherited from parents were larger in a US data set when they controlled for entrepreneurial education, business age, and industry. On the other hand, Bates (1990) found no evidence that occupational following of parents influenced the probability of survival of similar businesses.

Between them Amharic and Gurage business owners account for 72 percent of establishments in my sample. Although 43 percent of the sample are run by Amharic owners, the 29 percent share of Gurage owned businesses reflects a far higher rate 
business ownership among the Gurage than the Amhara since the Amharic ethnic group in the region's labor force is about 8 times that of the Gurage. And yet, with an average 6.5 years of schooling against 9.6 years for the Amhara and an overall sample average of 8.6 years, Gurage business owners are the least educated ethnic group within our sample. Only 10 percent of Gurage entrepreneurs also had formal vocational training against a corresponding figure 27 percent for the Amhara and an overall average of 21 percent. Turning to prior industry experience, the mean number of years of Gurage owners is slightly larger than the overall mean of 8 years. However, contrary to what their larger share of business ownership suggests, the proportion of Gurage owners who had prior experience as family workers or as self-employees is not statistically different from that of other groups.

\section{Results}

\section{Ethnicity Effects and Education in Business Size Determination}

Notice also in Table 1 that the average current size, the average start-up size, and the average annual growth rate since start-up are all significantly larger for Gurage-run businesses than for those run by members of other ethnic groups. I now turn to the task of isolating the role of ethnicity in generating this pattern from the influence of other factors. I present in Table 2 results of the estimation of equation (3) under alternative exclusion restrictions. As should be expected older businesses are normally larger (column 1): other things being equal, an establishment that has been in business twice as long as another is, on the average, 25 percent larger. Apart from industry, time of observation, individual establishment effects and the ethnicity of the owner of the business, the 'other things' include the education of the owner and his or her experience 
in the current industry prior to the start-up the business. A business is larger the greater is the number of years of schooling of its owner. It is also larger if the owner had formal vocational training. For every additional year of schooling of the owner, the business is 4.4 percent larger while, controlling for the age of the business and the number of years of schooling of the owner, businesses run by those with formal vocational training are 55 percent larger. The number of years of prior work- experience of the owner in the present industry is also an important influence. For every additional year of the same experience, a business is 2 percent larger. Further, controlling for the duration of prior industry experience, businesses of those for whom the experience involved self-employment in the industry are larger. On the other hand, businesses run by those who had previously worked in a family business in the same industry are about 60 percent smaller.

The result that interests me most in the Table is, however, that the ethnicity of the business owner is a very strong influence on the size of the business. Other things being equal, a Gurage-run business is, on the average, at least 26 percent larger than an Amharic- run business and 39 percent larger than a business run by an owner from other ethnic groups. The second most interesting aspect of the result is that the estimates and standard errors of the effect of ethnicity on business size are sensitive to the inclusion or exclusion of variables of the educational status of the owner. On the other hand, estimates of the effects of education and prior experience are fairly robust to the inclusion or otherwise of indicators of ethnicity. The second of these results is evident from a comparison of column 1 with column 2 . The sensitivity of estimated coefficients of ethnicity dummies to the inclusion of particular controls can be assessed by comparing column 1 with columns 3 to 5 . We see from the third column that the size advantage of Gurage-run businesses drops sharply when we exclude educational variables.

As already noted, the average number of years of schooling is significantly smaller for the Gurage than for any other ethnic group of business owners. The proportion of business owners who had been trained in a formal institution of vocational education is also significantly smaller for the Gurage. The result that the size advantage of Gurage-run businesses falls drastically when we fail to control for the education of the owner can 
therefore only mean that non-Gurage businesses would have been even less successful than Gurage-run businesses were it not for the greater schooling of their owners. This in turn means that the observed advantage of Gurage-run businesses depends on the trend in ethnic differences in investment in education, and need not therefore be permanent. It also implies that at least part of the observed ethnicity effect could be due to advantage that Gurage owners have over those from other ethnic groups in terms of some unmeasured ability such as drive or energy.

\section{The Effects of Ethnicity and Education on Start-up Size}

The effect of an entrepreneurial characteristic on current business size is a combination of the characteristic's influence on start-up size and its effect on subsequent growth. In Table 4, I report results of the estimation of equation (2) with a view to separating these two components. This I do by including the log of start-up size as a right-hand-side variable over and above those already included in the corresponding columns of Table 2. The procedure should filter out effects that are transmitted through start-up, size thereby leaving each coefficient as a measure of influence on growth only. As is to be expected, differences in start-up size explain a large fraction of variation in current size, the elasticity of current size with respect to start-up size standing at an average of 0.41 (column 1). More importantly, the introduction of start-up size reduces the magnitude of the coefficient of entrepreneurial ethnicity compared to the corresponding coefficient in Table 2. In particular it makes the size advantage of Gurgage-run businesses over businesses run by other non-Amharic owners fall from the figure of 39.2 percent in Table 2 to 28.9 percent. This means that the balance of about 10 percent size advantage is due to the fact that Gurage-run businesses star-up bigger. Dividing this figure by the estimated coefficient of the log of start-up size in the same equation suggests that the start-up size of Gurage-owned businesses is about 25 percent greater than the start-up size of the average business owned by an entrepreneurs from the other ethnic groups.

The inclusion of start-up size also significantly reduces the marginal effect of years of schooling of the business owner on current size. This again suggests that the reason that 
those with more schooling end up running larger businesses is partly because they startup bigger and partly because their businesses grow faster post-start up. However, somewhat surprisingly, the effect of vocational training on current size does not change with the inclusion of start-up size in the equation. In other words, businesses run by the vocationally trained are on the average larger, not because they start-up larger, but because they grow faster. Notice finally that the inclusion of start-up size sharply reduces the size disadvantage of businesses run by those who had previously been engaged in a family business in the same industry. This is largely because they start-up smaller: other things being equal, the start-up sizes of businesses run by those had worked in a family businesses are almost half of the start-up sizes of other businesses (Tables 2 and 3).

The coefficients of the ethnicity dummies in Table 3 measure the effect of the ethnicity of the business owner on the growth of the business since start-up. Like the overall effect of ethnicity on current size, these effects are sensitive to the inclusion of education variables in the size equation. As can be seen in columns 1 and 3 of the table the omission of the same variables drastically reduces ethnicity effects in growth. On the other hand we see from a comparison of column 1 with column 2 of the same table, that the effects of the business owner's schooling and vocational training on business growth are fairly robust to the inclusion or otherwise of ethnicity dummies among the controls.

\section{The Effects of Ethnicity and Education on Average Annual Growth Rates}

In Tables 4 and 5 I report results of the estimation of equations 5 and 4 respectively. Table 4 translates the results of Table 2 on the determination of current business size into statements about the annual growth rate the establishment since its founding. Table 5 is a similar recasting of the results of Table 3. Focusing on Table 5 first, the 39 percent size advantage of Gurage-run businesses over businesses run by other non-Amharic business owners that we read in the first column of Table 2 translates to a 7 percent advantage in the average annual growth rate since start-up (column 1). Likewise the 26 percent size advantage of Gurage businesses over Amharic businesses translates to a minimum of 5 percent advantage in the annual average growth rate. The 4.4 percent size advantage of an 
additional year of schooling of the business owner now means a 0.5 percent advantage in the annual average growth rate since start-up. The 55 percent size advantage of businesses run by the vocationally trained translates to a growth- rate advantage of 7 percent.

Like ethnicity effects in business size, ethnicity effects in rate of growth are sensitive to whether or not we control for the education of the owner. And similar to what happens as we move from the first column of Table 2 to the second column, the omission of education variables in Table 4 (columns 2 and 3 ) reduces the growth rate advantage of Gurage-run businesses. On the other hand, parallel to what we have seen in Table 2, the estimated effect of the schooling or vocational training of the business owner does not seem to vary much as we omit or add ethnicity dummies in the growth equation (column 5).

Just as the specifications of Table 2 lump the effect that a variable has on current size through its influence on start-up size with its impact on the rate of growth since start-up, the effects of a variable on the annual growth rate that we read from Table 4 combines direct effects with effects transmitted through start-up size. Including start-up size among the right hand side variables, as is done in Table 5, enables us to pick out the direct effects. Unlike the influence of start-up size on current size, however, the influence of start-up size on the growth rate is negative. ${ }^{9}$ Consequently, the direct effect of a variable on the average annual growth rate exceeds its overall effect if the variable increases both start-up size and the rate of growth. This is what we see when we compare the first column of Table 5 with the first column of Table 4 . Thus we see that the growth rate advantage of Gurage run businesses over businesses run by members of other nonAmharic ethnic groups rises from 7.2 percent in Table 4 to 10.1 percent as we move to Table 5. Similarly, the growth rate advantage of Gurage businesses over Amharic businesses rises from 5 percent in Table 5 to 7 percent in Table 5.

Like ethnicity, the number of years of schooling of the business owner influences both start-up size and growth since start-up. Its overall marginal effect on the annual growth rate as read from Table 4 is therefore smaller than the direct effect read from column 1 of

\footnotetext{
${ }^{9}$ On the average, businesses that start-up bigger do end-up bigger in the data, but this is in spite of the fact that they also grow slower.
} 
Table 5. On the other hand, because vocational training of the owner is not correlated with start-up size, its overall effect on the average annual growth rate is the same as the direct effect. Once again dropping the same education variables reduces ethnicity effects while the effect of education itself is robust to the inclusion or otherwise of ethnicity dummies in the growth rate equation.

\section{Summary and Conclusion}

This paper has sought to draw attention to the disparity that seems to exist among indigenous ethnic groups in Africa in business ownership rates and performance. Recently researchers have been asking why Asian or European ethnic minorities in the region are apparently more successful as entrepreneurs than African ethnic groups. Our understanding of the reasons for this phenomenon could be incomplete if we cannot explain also why some indigenous groups do better than others if African ethnic groups themselves do in fact differ in entrepreneurial performance.

Based on an analysis of data from a recent survey of owner-managed manufacturing businesses in Ethiopia, I find that an indigenous minority group, namely, the Gurage, happens to have a far higher rate of business ownership than other major ethnic groups as well as minorities. This seems to be the case partly because Gurage run businesses perform better. Controlling for the date of start-up, the time of observation, industry of activity, the education and prior industry of experience of the business owner, and unobservable establishment effects, the average Gurage-owned establishment is significantly larger. This is in part because the Gurage start-out bigger. It is partly because Gurage-run businesses also grow faster.

However, the Gurage are also the least educated group of business owners in my sample. They have a lower average of years of schooling than any other group, and a Gurage business owner is less likely to have had formal vocational training. At the same time the size of a business and its growth rate increase with the two education variables. The performance of other businesses relative to those run by the Gurage would therefore have 
been worse than what is reported here had the average level of education of their owners been lower than it actually is compared to that of Gurage owners. This in turn has two implications. One is that the reported ethnicity effects could partly reflect inter-ethnic differences in some ability that is not observable to researchers. The second is that the effects need not be permanent. Whether or not they will persist in the long-run will depend on the trend in the rate of investment in education of other ethnic groups relative to that of the Gurage.

It is important to bear in mind that the data analyzed here have two major limitations from the point of view of the issue at hand. One is that they do not include information on failed businesses. The second is that the sample is drawn entirely from manufacturing industries to the exclusion of businesses in services or in construction. It is possible that failure rates are higher among Gurage-run manufacturing businesses just as it is possible that the Gurage are doing worse than members of other ethnic groups outside of the manufacturing sector. If either of these possibilities is in fact true, my conclusion that Gurage entrepreneurs are on the average more successful than others would not necessarily be true. Neither possibility can be ruled out in the absence of better data, which in effect means longitudinal observations from industrial censuses rather than sector-specific sample surveys. However, existing studies of establishment survival and growth in developed economies show that the first of these possibilities is highly unlikely. A pattern that seems to emerge from findings of these studies is that a variable that is positively correlated with the size of a business is also positively associated with the probability of survival of the business. ${ }^{10}$ Thus, if establishments of the better educated happen to be larger among survivors, it is highly unlikely that business failure rates increase with entrepreneurial education. Casual observation suggests that the second possibility is not likely either: if anything, the advantage of the Gurage in business ownership rates seems to be more pronounced in trade or services.

\footnotetext{
${ }^{10}$ In all theoretical and empirical studies I know of covariates of size coincide with those of the probability of survival. There are quite a few studies here but see, for example, Dunne and Hughes (1994) and Evans (1987), where the key exogenous variables are business age and initial size. Estimation results of both studies show that the probability of survival increases with initial size and with age just as does current size. In Holtz-Eakin et al (1994) the same set of entrepreneurial characteristics determine the probability of
} 


\section{References}

Aldrich, H.E. and Waldinger, R. 1990. 'Ethnicity and Entrepreneurship.' Annual Review of Sociology. 16: 111-135.

Bates, T. 1990. 'Entrepreneur Human Capital Inputs and Small Business Longevity.' Review of Economics and Statistics 72: 551-559.

Dunne, P. and Hughes, A. 1994. ' Age , Size , Growth and Survival : UK Companies in the 1980s.' Journal of Industrial Economics 42: 115-140.

Evans, D. 1987. 'Tests of Alternative Theories of Firm Growth.' Journal of Political Economy 95: 657-674.

Fafchamps, M. 2000. 'Ethnicity and Credit in African Manufacturing.' Journal of Development Economics 61: 205-235.

Fairlie, R. and Meyer, B.1996. 'Ethnic and Racial Self-employment Differences and Possible Explanations.' Journal of Human Resources 21: 485-506.

Fisman, R. 2000. 'Ethnic Enclaves and Communal Enforcement: Evidence from Trade Credit Relationships.' Mimeo, Columbia University.

Hall, B. 1987. The Relationship between Firm Size and Firm Growth in the US Manufacturing Sector.' Journal of Industrial Economics 35: 583-606.

Holtz-Eakin , D., D. Joulfaian and H. Rosen. 1994. 'Sticking it Out : Entrepreneurial Survival and Liquidity Constraints.' Journal of Political Economy 102: 53-75.

Hopenhayn, H., 1992a. 'Entry, Exit, and Firm Dynamics in Long Run Equilibrium.' Econometrica, 60: 1127-1150.

Jovanovic, B., 1982. 'Selection and the Evolution of Industry.' Econometrica 50: 649670.

Jovanovic, B. and G. MacDonald. 1994. 'Competitive Diffusion.' Journal of Political Economy 102: 24-52.

Knight, F. H. 1921. Risk, Uncertainty and Profit. New York: Houghton Mifflin Company.

Lentz B. and Laband, D. 1990. 'Entrepreneurial Success and Occupational Inheritance Among Proprietors.' Canadian Journal of Economics 23: 563-578.

survival and size conditional on survival the sign of the marginal effect of a covariate of the probability of survival being the same as that of the effect of the same covariate on current size. 
Lippman, S. and Rumelt, R. 1982. 'Uncertain Immitability: Analysis of Inter-firm Differences in Efficiency Under Competetion.' Bell Journal of Economics 13: 418-438.

Lucas, R.E., Jr. 1978. 'On the Size Distribution of Business Firms.' Bell Journal of Economics 9: 508-523.

Martin, J. and Page, J. 1983. 'The Impact of Subsidies on X-efficiency in LDC Industry: Theory and Empirical Test.' The Review of Economics and Statistics 65: 608- 61.

Nelson, R. and Winter, S. 1978. 'Forces Generating and Limiting Concentration Under Schumpeterian Competetion.' Bell Journal of Economics 9:524-548.

Ramachandran, V. and Shah, M. 1999. 'Minority Entrepreneurs and Firm Performance in Sub-Saharan Africa.' Journal of Development Studies 36: 71-87.

Raturi, M. and Swamy, A. 1999. 'Explaining Ethnic Differentials in Credit Market Outcomes in Zimbabwe.' Economic Development and Cultural Change, pp. 586-604.

Yinger, J.M. 1985. 'Ethnicity'. Annual Review of Sociology 11:151-180 
Table 1: Descriptive Statistics

(Standard deviation in brackets)

\begin{tabular}{|c|c|c|c|c|}
\hline Variables & AII & Amharic-run & Gurage-run & Other \\
\hline \multicolumn{5}{|l|}{$\begin{array}{l}\text { Ethnic groups of owners: } \\
\text { amhara }\end{array}$} \\
\hline gurage & 0.29 & & & \\
\hline \multicolumn{5}{|l|}{$\begin{array}{l}\text { Other characteristics } \\
\text { of business owner: }\end{array}$} \\
\hline \multicolumn{4}{|l|}{ owns some other } & 0.26 \\
\hline \multirow[t]{2}{*}{ years of schooling } & 8.59 & 9.59 & 6.52 & 9.43 \\
\hline & [4.69] & [4.54] & [4.51] & [4.50] \\
\hline Had formal vocational training & 0.21 & 0.27 & 0.10 & 0.25 \\
\hline \multicolumn{5}{|l|}{ Prior industry experience: } \\
\hline \multirow[t]{2}{*}{ number of years } & 8.12 & 8.51 & 8.59 & 7.98 \\
\hline & {$[9.35]$} & [10.07] & [9.75] & [9.15] \\
\hline worked in a family business & 0.19 & 0.27 & 0.16 & 0.20 \\
\hline worked as an employee & 0.54 & 0.55 & 0.64 & 0.51 \\
\hline was self-employed & 0.11 & 0.13 & 0.12 & 0.11 \\
\hline \multicolumn{5}{|l|}{ Industry groups: } \\
\hline garment or leather goods & 0.32 & 0.24 & 0.56 & 0.23 \\
\hline wood or metal work & 0.24 & 0.27 & 0.09 & 0.30 \\
\hline textiles & 0.19 & 0.20 & 0.17 & 0.21 \\
\hline other & 0.25 & 0.29 & 0.19 & 0.27 \\
\hline \multicolumn{5}{|l|}{$\begin{array}{l}\text { Other establishment } \\
\text { characteristics: }\end{array}$} \\
\hline \multicolumn{5}{|l|}{$\log$ (number of full-time } \\
\hline \multirow[t]{2}{*}{ employees) } & 2.22 & 2.09 & 2.42 & 2.11 \\
\hline & [1.03] & {$[0.98]$} & [1.03] & [0.99] \\
\hline age of establishment & 14.15 & 13.17 & 15.29 & 13.46 \\
\hline \multirow[t]{2}{*}{ log (age of establishment) } & 2.28 & 2.16 & 2.36 & 2.22 \\
\hline & {$[0.96]$} & {$[0.98]$} & {$[0.97]$} & [0.96] \\
\hline $\begin{array}{l}\text { Number of full-time employees } \\
\text { at start up }\end{array}$ & 6.13 & 4.89 & 6.93 & 5.65 \\
\hline \multicolumn{5}{|l|}{$\log$ (number of full-time employ- } \\
\hline \multirow[t]{2}{*}{ ees at start-up ) } & 1.60 & $\begin{array}{r}1.43 \\
1.021\end{array}$ & 1.75 & 1.52 \\
\hline \multirow{2}{*}{\multicolumn{5}{|c|}{ average annual growth rate since }} \\
\hline & & & & \\
\hline start-up & 0.054 & $\begin{array}{l}0.047 \\
0.1191\end{array}$ & $\begin{array}{l}0.088 \\
10.1381\end{array}$ & $\begin{array}{l}0.037 \\
10.1311\end{array}$ \\
\hline \multicolumn{5}{|l|}{ Year of observation: } \\
\hline 1995 & 0.37 & 0.39 & 0.35 & 0.39 \\
\hline 1994 & 0.40 & 0.39 & 0.35 & 0.39 \\
\hline Number of observations & 296 & 121 & 93 & 82 \\
\hline
\end{tabular}


Table 2: GLS Estimation Results of Equation (3)

Dependent variable $=\log$ of number of full-time employees.

\begin{tabular}{|c|c|c|c|c|c|}
\hline \multirow[t]{2}{*}{ Variables } & \multicolumn{5}{|c|}{ Specification } \\
\hline & $(1)$ & (2) & (3) & (4) & $(5)$ \\
\hline \multirow[t]{2}{*}{ log of age of establishment } & 0.260 & 0.261 & 0.201 & 0.239 & 0.201 \\
\hline & $(3.62)$ & $(3.61)$ & $(2.73)$ & (3.31) & $(2.76)$ \\
\hline \multirow[t]{2}{*}{ owns some other establishment(s) } & 0.114 & 0.126 & 0.012 & 0.044 & -0.013 \\
\hline & $(0.66)$ & $(0.71)$ & $(0.06)$ & $(0.25)$ & $(0.07)$ \\
\hline \multicolumn{6}{|l|}{ Year of observation: } \\
\hline \multirow[t]{2}{*}{1995} & -0.161 & -0.161 & -0.143 & -0.119 & -0.110 \\
\hline & $(2.83)$ & $(2.89)$ & $(2.53)$ & $(2.28)$ & $(2.12)$ \\
\hline \multirow[t]{2}{*}{1994} & -0.157 & -0.157 & -0.148 & -0.118 & -0.115 \\
\hline & $(2.95)$ & $(3.01)$ & $(2.81)$ & $(2.46)$ & $(2.41)$ \\
\hline \multicolumn{6}{|l|}{ Ethnic group: } \\
\hline \multirow[t]{2}{*}{ amhara } & 0.134 & & 0.113 & 0.087 & 0.086 \\
\hline & $(0.96)$ & & $(0.79)$ & $(0.63)$ & $(0.61)$ \\
\hline \multirow[t]{2}{*}{ gurage } & 0.392 & & 0.212 & 0.339 & 0.220 \\
\hline & $(2.10)$ & & $(1.09)$ & $(1.76)$ & (1.13) \\
\hline \multicolumn{6}{|l|}{ Education: } \\
\hline \multirow[t]{2}{*}{ years of schooling } & 0.044 & 0.034 & & 0.027 & \\
\hline & $(2.39)$ & $(1.86)$ & & $(1.44)$ & \\
\hline \multirow[t]{2}{*}{ Had formal vocational training } & 0.553 & 0.554 & & 0.464 & \\
\hline & $(2.82)$ & $(2.74)$ & & (2.31) & \\
\hline \multicolumn{6}{|l|}{ Prior industry experience: } \\
\hline \multirow[t]{2}{*}{ Number of years } & 0.018 & 0.017 & 0.009 & & \\
\hline & $(1.98)$ & $(1.83)$ & $(0.92)$ & & \\
\hline \multirow[t]{2}{*}{ worked in a family business } & -0.622 & -0.595 & -0.407 & & \\
\hline & $(2.75)$ & $(2.59)$ & $(1.70)$ & & \\
\hline \multirow[t]{2}{*}{ worked as an employee } & -0.007 & 0.027 & -0.023 & & \\
\hline & $(0.04)$ & $(0.15)$ & $(0.12)$ & & \\
\hline \multirow[t]{2}{*}{ was self-employed } & 0.133 & 0.133 & 0.128 & & \\
\hline & $(1.44)$ & $(1.45)$ & $(1.39)$ & & \\
\hline \multicolumn{6}{|l|}{ Industry group: } \\
\hline \multirow[t]{2}{*}{ garment or leather goods } & -0.501 & -0.440 & -0.689 & -0.481 & -0.661 \\
\hline & $(2.36)$ & $(2.05)$ & $(3.07)$ & $(2.22)$ & $(3.03)$ \\
\hline \multirow[t]{2}{*}{ wood or metal work } & -0.633 & -0.679 & -0.625 & -0.620 & -0.640 \\
\hline & $(3.24)$ & $(3.44)$ & $(3.03)$ & $(3.23)$ & $(3.23)$ \\
\hline \multirow[t]{2}{*}{ textiles } & -0.547 & -0.630 & -0.907 & -0.763 & -0.991 \\
\hline & $(2.14)$ & $(2.42)$ & $(3.52)$ & $(3.02)$ & (3.99) \\
\hline \multirow[t]{2}{*}{ Constant } & 1.514 & 1.756 & 2.415 & 1.861 & 2.432 \\
\hline & $(4.43)$ & $(5.30)$ & $(9.54)$ & $(5.56)$ & (9.91) \\
\hline R-squared: & & & & & \\
\hline between & 0.40 & 0.33 & 0.26 & 0.32 & 0.23 \\
\hline overall & 0.37 & 0.30 & 0.24 & 0.30 & 0.21 \\
\hline Wald Chi-sq. & 61.14 & 53.66 & 37.51 & 44.67 & 32.06 \\
\hline Rho** & 0.88 & 0.89 & 0.90 & 0.89 & 0.90 \\
\hline Observations & 296 & 296 & 296 & 296 & 296 \\
\hline Establishments & 114 & 114 & 114 & 114 & 114 \\
\hline
\end{tabular}


Table 3: GLS Estimation Result of Equation (2) ${ }^{*}$

Dependent variable $=\log$ of number of full-time employees.

\begin{tabular}{|c|c|c|c|c|c|}
\hline \multirow[t]{2}{*}{ Variables } & \multirow[b]{2}{*}{$(1)$} & \multicolumn{2}{|c|}{ Specification } & \multirow[b]{2}{*}{$(4)$} & \multirow[b]{2}{*}{ (5) } \\
\hline & & $(2)$ & (3) & & \\
\hline \multirow[t]{2}{*}{$\log$ of number of employees at start-up } & 0.408 & 0.433 & 0.447 & 0.415 & 0.435 \\
\hline & $(4.67)$ & $(4.97)$ & $(4.78)$ & $(4.91)$ & $(4.90)$ \\
\hline \multirow[t]{2}{*}{ log of age of establishment } & 0.261 & 0.261 & 0.212 & 0.265 & 0.229 \\
\hline & $(3.86)$ & $(3.85)$ & $(3.05)$ & (3.93) & $(3.36)$ \\
\hline \multirow[t]{2}{*}{ owns some other establishment(s) } & 0.125 & 0.138 & 0.040 & 0.045 & -0.007 \\
\hline & $(0.79)$ & $(0.85)$ & $(0.23)$ & $(0.28)$ & $(0.04)$ \\
\hline \multicolumn{6}{|l|}{ Year of observation: } \\
\hline \multirow[t]{2}{*}{1995} & -0.157 & -0.155 & -0.143 & -0.126 & -0.118 \\
\hline & $(2.80)$ & $(2.81)$ & $(2.57)$ & $(2.44)$ & $(2.30)$ \\
\hline \multirow[t]{2}{*}{1994} & -0.152 & -0.150 & -0.146 & -0.120 & -0.118 \\
\hline & $(2.89)$ & $(2.90)$ & $(2.79)$ & $(2.52)$ & $(2.48)$ \\
\hline \multicolumn{6}{|l|}{ Ethnic group: } \\
\hline \multirow[t]{2}{*}{ amhara } & 0.128 & & 0.113 & 0.107 & 0.108 \\
\hline & $(0.97)$ & & $(0.83)$ & $(0.81)$ & $(0.80)$ \\
\hline \multirow[t]{2}{*}{ gurage } & 0.289 & & 0.135 & 0.274 & 0.164 \\
\hline & $(1.63)$ & & $(0.74)$ & $(1.53)$ & $(0.91)$ \\
\hline \multicolumn{6}{|l|}{ Education: } \\
\hline \multirow[t]{2}{*}{ years of schooling } & 0.033 & 0.025 & & 0.022 & \\
\hline & $(1.89)$ & $(1.50)$ & & $(1,32)$ & \\
\hline \multirow[t]{2}{*}{ Had formal vocational training } & 0.557 & 0.560 & & 0.451 & \\
\hline & $(3.11)$ & $(3.08)$ & & $(2.50)$ & \\
\hline \multicolumn{6}{|l|}{ Prior industry experience: } \\
\hline \multirow[t]{2}{*}{ Number of years } & 0.011 & 0.010 & 0.002 & & \\
\hline & $(1.23)$ & $(1.10)$ & $(0.25)$ & & \\
\hline \multirow[t]{2}{*}{ worked in a family business } & -0.431 & -0.390 & -0.233 & & \\
\hline & $(2.04)$ & $(1.84)$ & $(1.05)$ & & \\
\hline \multirow[t]{2}{*}{ worked as an employee } & 0.221 & 0.261 & 0.215 & & \\
\hline & $(1.30)$ & $(1.52)$ & $(1.19)$ & & \\
\hline \multirow[t]{2}{*}{ was self-employed } & 0.125 & 0.124 & 0.121 & & \\
\hline & $(1.37)$ & $(1.37)$ & $(1.33)$ & & \\
\hline Industry group: & & & & & \\
\hline garment or leather goods & -0.435 & -0.393 & -0.601 & -0.379 & -0.544 \\
\hline & $(2.22)$ & $(2.02)$ & $(2.91)$ & $(1.92)$ & $(2.72)$ \\
\hline wood or metal work & -0.523 & -0.552 & -0.508 & -0.478 & -0.495 \\
\hline & $(2.85)$ & $(2.99)$ & $(2.62)$ & $(2.66)$ & $(2.66)$ \\
\hline textiles & -0.442 & -0.495 & -0.732 & -0.581 & -0.777 \\
\hline & $(1.87)$ & $(2.08)$ & $(3.06)$ & $(2.52)$ & (3.39) \\
\hline Constant & 0.821 & 0.963 & 1.494 & 1.107 & 1.584 \\
\hline & $(2.39)$ & $(2.86)$ & $(5.01)$ & $(3.30)$ & $(5.67)$ \\
\hline R-squared: & & & & & \\
\hline between & 0.50 & 0.46 & 0.39 & 0.45 & 0.38 \\
\hline overall & 0.46 & 0.42 & 0.36 & 0.42 & 0.35 \\
\hline Wald Chi-sq. & 95.65 & 90.10 & 67.73 & & 963.31 \\
\hline $\mathrm{Rho}^{* *}$ & 0.85 & 0.86 & 0.88 & 0.87 & \\
\hline Observations & 296 & 296 & 296 & 296 & 296 \\
\hline Establishments & 114 & 114 & 114 & 114 & 114 \\
\hline
\end{tabular}


Table 4: GLS Estimation Result of Equation (5)*

Dependent variable= Average annual growth rate of number of full-time employees since start-up

\begin{tabular}{|c|c|c|c|c|c|}
\hline \multirow[t]{2}{*}{ Variable } & \multicolumn{5}{|c|}{ Specification } \\
\hline & (1) & (2) & (3) & (4) & (5) \\
\hline \multirow[t]{2}{*}{ log of age of establishment } & -0.063 & -0.062 & -0.067 & -0.057 & -0.061 \\
\hline & (5.11) & $(4.95)$ & (5.49) & $(4.73)$ & (5.16) \\
\hline \multirow[t]{2}{*}{ owns some other establishment(s) } & 0.038 & 0.039 & 0.031 & 0.028 & 0.023 \\
\hline & $\mid(1.41)$ & (1.43) & (1.14) & $(1.07)$ & $(0.85)$ \\
\hline \multicolumn{6}{|l|}{ Year of observation: } \\
\hline \multirow[t]{2}{*}{1995} & -0.030 & -0.031 & -0.029 & -0.026 & -0.026 \\
\hline & (2.35) & $(2.46)$ & (2.32) & (2.26) & (2.20) \\
\hline \multirow[t]{2}{*}{1994} & -0.027 & -0.028 & -0.027 & -0.023 & -0.023 \\
\hline & $(2.25)$ & (2.33) & (2.26) & (2.06) & (2.06) \\
\hline \multicolumn{6}{|l|}{ Ethnic group: } \\
\hline \multirow[t]{2}{*}{ amhara } & 0.021 & & 0.022 & 0.023 & 0.024 \\
\hline & $(0.86)$ & & $(0.86)$ & $(0.96)$ & $(0.97)$ \\
\hline \multirow[t]{2}{*}{ gurage } & 0.072 & & 0.063 & 0.077 & 0.066 \\
\hline & (2.33) & & (2.09) & (2.51) & (2.21) \\
\hline \multicolumn{6}{|l|}{ Education: } \\
\hline \multirow[t]{2}{*}{ years of schooling } & 0.002 & 0.000 & & 0.003 & \\
\hline & $(0.74)$ & $(0.13)$ & & $(0.98)$ & \\
\hline \multirow[t]{2}{*}{ Had formal vocational training } & 0.053 & 0.053 & & 0.041 & \\
\hline & $(1.77)$ & (1.73) & & (1.42) & \\
\hline \multicolumn{6}{|l|}{ Prior industry experience: } \\
\hline \multirow[t]{2}{*}{ Number of years } & -0.001 & -0.001 & -0.002 & & \\
\hline & $(0.93)$ & $(1.02)$ & (1.41) & & \\
\hline \multirow[t]{2}{*}{ worked in a family business } & -0.017 & -0.013 & -0.003 & & \\
\hline & $(0.49)$ & $(0.38)$ & $(0.09)$ & & \\
\hline \multirow[t]{2}{*}{ worked as an employee } & 0.063 & 0.069 & 0.059 & & \\
\hline & (2.32) & $(2.48)$ & (2.18) & & \\
\hline \multirow[t]{2}{*}{ was self-employed } & 0.022 & 0.023 & 0.023 & & \\
\hline & $(1.10)$ & (1.14) & $(1.12)$ & & \\
\hline \multicolumn{6}{|l|}{ Industry group: } \\
\hline \multirow[t]{2}{*}{ garment or leather goods } & $\mid-0.023$ & -0.012 & -0.037 & -0.014 & -0.031 \\
\hline & $(0.68)$ & $(0.34)$ & (1.13) & $(0.45)$ & $(0.99)$ \\
\hline \multirow[t]{2}{*}{ wood or metal work } & 0.022 & 0.012 & 0.024 & 0.025 & 0.023 \\
\hline & $(0.66)$ & $(0.35)$ & $(0.73)$ & $(0.79)$ & $(0.72)$ \\
\hline \multirow[t]{2}{*}{ textiles } & -0.021 & -0.037 & -0.044 & -0.024 & -0.045 \\
\hline & $(0.53)$ & $(0.92)$ & $(1.17)$ & (0.64) & (1.26) \\
\hline \multirow[t]{2}{*}{ Constant } & 0.152 & 0.194 & 0.208 & 0.159 & 0.215 \\
\hline & $(2.74)$ & (3.64) & $(5.24)$ & $(3.01)$ & (5.51) \\
\hline R-squared: & & & & & \\
\hline between & 0.23 & 0.18 & 0.19 & 0.21 & 0.17 \\
\hline overall & 0.23 & 0.18 & 0.20 & 0.21 & 0.17 \\
\hline Wald Chi-sq. & 67.22 & 61.01 & 62.44 & 60.34 & 56.24 \\
\hline $\mathrm{Rho}^{* \star}$ & 0.74 & 0.75 & 0.75 & 0.73 & 0.74 \\
\hline Observations & 296 & 296 & 296 & 296 & 296 \\
\hline Establishments & 114 & 114 & 114 & 114 & 114 \\
\hline
\end{tabular}

${ }^{\star}$ Absolute value of $z$-statistics in parentheses

** Fraction of variance due to establishment effects 
Table 5: GLS Estimation Result of Equation (5)*

Dependent variable $=$ Average annual growth rate of number of full-time employees since start-up

\begin{tabular}{|c|c|c|c|c|c|}
\hline \multirow[t]{2}{*}{ Variable } & \multicolumn{5}{|c|}{ Speciflcation } \\
\hline & (1) & (2) & (3) & (4) & (5) \\
\hline \multirow[t]{2}{*}{ log of age of establishment } & -0.063 & -0.062 & -0.067 & -0.057 & -0.061 \\
\hline & $(5.11)$ & (4.95) & $(5.49)$ & $(4.73)$ & $(5.16)$ \\
\hline \multirow[t]{2}{*}{ owns some other establishment(s) } & 0.038 & 0.039 & 0.031 & 0.028 & 0.023 \\
\hline & $(1.41)$ & (1.43) & $(1.14)$ & $(1.07)$ & $(0.85)$ \\
\hline \multicolumn{6}{|l|}{ Year of observation: } \\
\hline \multirow[t]{2}{*}{1995} & -0.030 & -0.031 & -0.029 & -0.026 & -0.026 \\
\hline & $(2.35)$ & $(2.46)$ & (2.32) & (2.26) & $(2.20)$ \\
\hline \multirow[t]{2}{*}{1994} & -0.027 & -0.028 & -0.027 & -0.023 & -0.023 \\
\hline & $(2.25)$ & (2.33) & (2.26) & $(2.06)$ & $(2.06)$ \\
\hline \multicolumn{6}{|l|}{ Ethnic group: } \\
\hline \multirow[t]{2}{*}{ amhara } & 0.021 & & 0.022 & 0.023 & 0.024 \\
\hline & $(0.86)$ & & $(0.86)$ & $(0.96)$ & $(0.97)$ \\
\hline \multirow[t]{2}{*}{ gurage } & 0.072 & & 0.063 & 0.077 & 0.066 \\
\hline & $(2.33)$ & & $(2.09)$ & (2.51) & $(2.21)$ \\
\hline \multicolumn{6}{|l|}{ Education: } \\
\hline \multirow[t]{2}{*}{ years of schooling } & 0.002 & 0.000 & & 0.003 & \\
\hline & $(0.74)$ & $(0.13)$ & & $(0.98)$ & \\
\hline \multirow[t]{2}{*}{ Had formal vocational training } & 0.053 & 0.053 & & 0.041 & \\
\hline & $(1.77)$ & $(1.73)$ & & $(1.42)$ & \\
\hline \multicolumn{6}{|l|}{ Prior industry experience: } \\
\hline \multirow[t]{2}{*}{ Number of years } & -0.001 & -0.001 & -0.002 & & \\
\hline & $(0.93)$ & $(1.02)$ & $(1.41)$ & & \\
\hline \multirow[t]{2}{*}{ worked in a family business } & -0.017 & -0.013 & -0.003 & & \\
\hline & $(0.49)$ & $(0.38)$ & $(0.09)$ & & \\
\hline \multirow[t]{2}{*}{ worked as an employee } & 0.063 & 0.069 & 0.059 & & \\
\hline & (2.32) & (2.48) & (2.18) & & \\
\hline \multirow[t]{2}{*}{ was self-employed } & 0.022 & 0.023 & 0.023 & & \\
\hline & |(1.10) & (1.14) & (1.12) & & \\
\hline \multicolumn{6}{|l|}{ Industry group: } \\
\hline \multirow[t]{2}{*}{ garment or leather goods } & -0.023 & -0.012 & -0.037 & -0.014 & -0.031 \\
\hline & $(0.68)$ & $(0.34)$ & $(1.13)$ & $(0.45)$ & $(0.99)$ \\
\hline \multirow[t]{2}{*}{ wood or metal work } & 0.022 & 0.012 & 0.024 & 0.025 & 0.023 \\
\hline & $(0.66)$ & $(0.35)$ & $(0.73)$ & $(0.79)$ & $(0.72)$ \\
\hline \multirow[t]{2}{*}{ textiles } & -0.021 & -0.037 & -0.044 & -0.024 & -0.045 \\
\hline & $(0.53)$ & $(0.92)$ & $(1.17)$ & $(0.64)$ & $(1.26)$ \\
\hline \multirow[t]{2}{*}{ Constant } & 0.152 & 0.194 & 0.208 & 0.159 & 0.215 \\
\hline & $(2.74)$ & (3.64) & $(5.24)$ & (3.01) & (5.51) \\
\hline R-squared: & & & & & \\
\hline between & 0.23 & 0.18 & 0.19 & 0.21 & 0.17 \\
\hline overall & 0.23 & 0.18 & 0.20 & 0.21 & 0.17 \\
\hline Wald Chi-sq. & 67.22 & 61.01 & 62.44 & 60.34 & 56.24 \\
\hline Rho** & 0.74 & 0.75 & 0.75 & 0.73 & 0.74 \\
\hline Observations & 296 & 296 & 296 & 296 & 296 \\
\hline Establishments & 114 & 114 & 114 & 114 & 114 \\
\hline
\end{tabular}

*Absolute value of z-statistics in parentheses

** Fraction of variance due to establishment effects 



\section{Policy Research Working Paper Series}

\section{Title}

WPS2518 Can Reforming Global Institutions Help Developing Countries Share More in the Benefits from Globalization?

WPS2519 is Investment in Africa Too Low or Too High? Macro and Micro Evidence

WPS2520 Wage Effects of Unions and Industrial Councils in South Africa

WPS2521 Labor Market Rigidity and the Success of Economic Reforms across More than 100 Countries

WPS2522 Trade in International Maritime Services: How Much Does Policy Matter?

WPS2523 Can Duty Drawbacks Have a Protectionist Bias? Evidence from Mercosur

WPS2524 Racing to the Bottom? Foreign Investment and Air Pollution in Developing Countries

WPS2525 Measuring Education Inequality: Gini Coefficients of Education

WPS2526 Linking Participatory Poverty Assessments to Policy and Policymaking: Experience from Vietnam

\section{Author}

Andrés Solimano

Shantayanan Devarajan William R. Easterly Howard Pack

Kristin F. Butcher Cecilia Elena Rouse

Alvaro Forteza

Martin Rama

Carsten Fink Aaditya Mattoo lleana Cristina Neagu

Olivier Cadot

Jaime de Melo

David Wheeler

Vinod Thomas

Yan Wang

Xibo Fan

Carrie Turk

Alice Mesnard

Martin Ravallion

A Nonlinear Microeconomic Model

Of Wealth Effects on Self-Employment

WPS2528 Poverty and Public Celebrations in Rural India

Vijayendra Rao

Graciela Kaminsky Richard Lyons Sergio Schmukler
Date

January 2001

January 2001

January 2001

Contact for paper

R. Bonfield 31248

H. Sladovich 37698

January 2001

P. Sader 33902

January 2001

P. Sader 33902

January 2001

January 2001

L. Tabada 36896

D. Wheeler 33401

January 2001

A. Datoloum 36334

H. Sutrisna 88032

January 2001

P. Sader 33902

January 2001

P. Sader 33902

January 2001

E. Khine

37471 


\section{Policy Research Working Paper Series}

\begin{tabular}{|c|c|c|c|c|}
\hline & Title & Author & Date & $\begin{array}{l}\text { Contact } \\
\text { for papar }\end{array}$ \\
\hline WPS2530 & $\begin{array}{l}\text { The Role of Nongovernmental } \\
\text { Organizations in Primary Education: } \\
\text { A Study of Six NGOs in India }\end{array}$ & Shanti Jagannathan & January 2001 & $\begin{array}{l}\text { S. Kumar } \\
87021\end{array}$ \\
\hline WPS2531 & $\begin{array}{l}\text { Growth Implosions, Debt Explosions, } \\
\text { and My Aunt Marilyn: Do Growth } \\
\text { Slowdowns Cause Public Debt Crises? }\end{array}$ & William Easterly & January 2001 & $\begin{array}{l}\text { K. Labrie } \\
31001\end{array}$ \\
\hline WPS2532 & $\begin{array}{l}\text { Market Presence, Contestability, and } \\
\text { the Terns-of-Trade Effects of } \\
\text { Regional Integration }\end{array}$ & $\begin{array}{l}\text { Maurice Schiff } \\
\text { Won Chang }\end{array}$ & January 2001 & $\begin{array}{l}\text { L. Tabada } \\
36896\end{array}$ \\
\hline WPS2533 & $\begin{array}{l}\text { How Much War Will We See? } \\
\text { Estimating the Incidence of Civil } \\
\text { War in } 161 \text { Countries }\end{array}$ & $\begin{array}{l}\text { Ibrahim Elbadawi } \\
\text { Nicholas Sambanis }\end{array}$ & January 2001 & H. Sladovich \\
\hline
\end{tabular}

